\title{
EDITORIAL
}

\section{Greetings from the new editors}

IT IS A great honor, privilege and pleasure to step up as the new editors of lambda nordica. The change of editors can be likened to a crossroads of sorts in the journey of a journal. Whilst we will build on the established practices and ambitions of lambda that we inherit from the previous editors, Ulrika Dahl and Jenny Björklund, new editors also necessarily mean new perspectives and ideas. With our first editorial, we would like to invite readers into our ongoing conversations and thoughts on the journey ahead for lambda nordica, both as an academic journal and as a broader platform to support and promote queer scholarship, debate, and community, inside and beyond the academy. Certainly, the lambda nordica of today is a testament to the dedication to LGBTQ+ and queer studies, and to struggles and engagement with these concepts and fields, that in the Nordic context stretches over decades, and we are happy and humbled to take our departure in the formidable legacy of Björklund and Dahl.

In the past decade, editors Dahl and Björklund have, with the support of the Board, undertaken the delicate and difficult task to establish lambda nordica as the principal academic journal for queer and LGBTQ+ scholarship in Nordic Europe, all the while resisting the powerful push towards incorporation into the commercialized academic publishing industry. And so today, lambda nordica is one of the very few independent peer-reviewed academic journals in the world in the field of queer and 
LGBTQ+ studies, and one that actively promotes writing in the English and Scandinavian languages side by side. Given the harsh conditions for academic publishing, with articles kept inaccessible behind pay-walls, multi-language journals vanishing as English consolidates further as the lingua franca of academic publishing, with elitist hierarchization of publishing platforms having detrimental consequences for the quantitative metrics based on clicks and citations, with institutional reputation (often) standing in for quality of content, and authors having to sign off their copyrights to publishing houses, this is no small feat. We are deeply committed to continuing on the path of independent publishing, and it is our ambition to queerly develop the generative and collaborative potentials of such an outsider position even further in the years to come.

A major objective for us is to continue the endeavor to enhance the quality of papers, the editorial feedback and author support - especially for junior scholars - and to entice more authors to send their manuscripts to lambda nordica. As part of this ambition we have extended the journal's editorial board to reflect the diversity and interdisciplinarity of Nordic queer studies and its scholarly priorities, with the aim to engage more scholars in what Björklund and Dahl call the 'ecology of editing and publishing' (Björklund and Dahl 2020, Io). We extend our gratitude to the two members of the previous editorial board, instated in 20I7, that now take their leave: Professor Jens Rydström of Lund University, and Dr. Kaisa Ilmonen of University of Turku. The new editorial board consists of six members: Postdoctoral Fellow Julian Honkasalo of Helsinki University, Postdoctoral Fellow Elisabeth Stubberud of the Norwegian University of Science and Technology (NTNU), Assistant Professor Íris Ellenberger of University of Iceland, Associate Professor Michael Nebeling Petersen of University of Southern Denmark, Professor Anu Koivunen of Tampere and Stockholm University, and Professor Ulrika Dahl of Uppsala University. Together they provide an inspiring and important diversity with respect to geographical location, disciplinary expertise, editorial experience and related interests, and we are extremely excited about the prospect of working with them in the next couple of years. 
We inherit the editorship at a time of considerable interest in, but also critique of, queer life and politics, in the Nordic region and in the world at large. Queer and LGBTQ+ research in the Nordic region is at best a small field and remains fairly poorly institutionalized in Nordic universities. Anti-gender campaigns gain popular support, right-wing politics turn mainstream, challenges to democratic processes and ideals undermine work in civil society in general and work for and by minorities in particular, climate change is forever altering our natural environment and in turn society. 'Emergent homonationalisms' and 'national and regional exceptionalism' in all of the Nordic nations make it clear that there is an urgent need for dedicated research and knowledge dissemination (Lykke 2020, II 2). Overshadowing it all, the Covid-I9 pandemic has wreaked havoc in our everyday lives, and made it painfully apparent that the workings of Covid-I9 amplify the already established systems of discrimination and violence, and hit the groups stratified by class, racial, sexist, heteronormative and ableist structures the hardest, those already living under what black history and literary scholar Saidiya Hartman calls "the everyday state of emergency" (Hartman 2020).

All these events have profound effects on scholarly activities and possibilities, on all levels; they affect teaching, research, funding, job searching, and publishing. Whilst we see a profound need to care for and safeguard queer scholarship and scholars - and lambda nordica is an important forum for doing just that - it is also a principal ambition in our editorship to place renewed emphasis on necessary reconsiderations and critiques of queer studies in contemporary academia. Part of this work, we imagine, centers on the Nordic location of the journal and its editorial community. As Björklund and Dahl point out in their last editorial: "what counts as Nordic as well as what goes on in the Nordic region remains a contested, complex, and, above all, productive question" (Björklund and Dahl 2020, Io). How might this Nordic specificity shape, but also reflect, the interdisciplinary field of queer studies in relation to other national and transnational contexts; specifically in respect of the dynamics between theory and data? It has been argued that Nordic queer scholars tend to acquire terminology and theoreti- 
cal figurations from Anglo-U.S. scholars whose empirical basis is vastly different from their own, but it is also our experience that, as scholars writing about contexts outside of the U.S., we are often asked to develop our arguments about the specificity of the region on which we write (the Nordic, the Chinese or other), which we believe serves to exceptionalize the 'provincial' Other as a pendant to the 'universal' (i.e. the U.S. centre). So, how can Nordic particularity, in terms of knowledge production and theory, meaningfully challenge the Anglo-U.S. dominance of queer studies, in ways that do not fetishize empiricism but demand "that theorizations be accountable to their objects of study" yet do not fall back on a "logic of enumeration" (Boellstorff 2007 , I9)? In short, we would argue that the Nordic location has the potential to complicate queer theory 'proper', to further challenge normalizing universalisms and unequal dynamics in and of queer and LGBTQ + research in contemporary academia. It is an explicit ambition of ours to facilitate this queering potential in our editorship of lambda nordica in the coming years.

One of the most persistent scholarly and political controversies that has shaped the field of queer studies is that of the legacy of queer pedagogy, that argues for the possibilities of a disruptive democratization of higher education, and the assertion that this legacy is reduced to academic elitist interest in postmodern, anti-identitarian abstract theory at the expense of material concerns and grounded activist commitments (Brim 2020). As editors we are particularly committed to making lambda nordica a vibrant platform for the kind of queer theorizing that challenges normative inequalities and normative assumptions in the field of intersectional gender and sexuality research, as it is our firm belief that there is no proper object of queer studies, that queer studies itself argues against proper objects. In the upcoming issues of lambda, themes as diverse as Nordic queer cinema, the term 'skev' and queer notions of bodies, will be explored.

\section{This issue}

This issue spans a wide range of topics and contains three research articles, one essay, two shorter We're here texts, and an obituary for one of the pioneers of LGBTQ+ organizing and struggle in Sweden, Anna 
Mohr. Starting, quite literally, with the surface, we are very pleased that visual artist Ester Fleckner, who divides her time between Germany and Denmark, has generously allowed us to use her piece Jeg navigerer $i$ kollisioner \#2 (I navigate in collisions \#2) as cover art for our first issue as editors. Fleckner works from queer epistemology, inverting "the value of failure, unfinishedness, and displacement to arrive at chaotic and intuitive ways of knowing" (Fleckner). Jeg navigerer $i$ kollisioner (I navigate in collisions), $I-I 2,2014^{-2015}$, is a series of woodcut prints that plays with the notion of the family tree, drawing into question the assumed naturalness of some relations over others. The series can be described as pseudo-scientific drawings that purport to map out a system of signs indexing sexual organs - anus-stars and clit-dicks - familiar from elsewhere in Fleckner's practice.

Katharina Kehl's article revisits existing critiques of the concepts of homonormativity, homonationalism and homocolonialism in queer struggles for rights and recognition, in the timely context of rising nationalist backlashes against LGBTQ + rights globally. Kehl, in line with Jasbir Puar, argues for the importance of (re)centering the racialized nature of sexualized/gendered difference in homonationalism, and discusses the excessive potential of 'gay-rights-as-human-rights' discourses. Kehl applies Alexander Weheliye's "Habeas Viscus" in an effort to revitalize queer studies' theoretical engagement with questions of racialization and colonialism, and to help expand our understandings of intersectional queer complexities beyond framings anchored in binary logics and politics of recognition.

T. Odland approaches the naturalization of gender classification as an instrument for the state to manage populations, arguing, in line with trans scholars Dean Spade and Toby Beauchamp, that even projects that aim to include trans and intersex people in administrative systems have detrimental effects on these groups. Through a meticulous discourse analysis, following Laclau and Mouffe, of the Official Report of the Swedish Government Transpersoner i Sverige (SOU 2017:92), Odland concludes that the violent, structural effects of administrative systems are covered up, as gender classification is naturalized as a tool for governance, and 
that the focus on the lack of knowledge, and the need for more knowledge about trans people's living conditions, plays a part in this naturalization of state surveillance and regimentation of the population.

Anna Bark Persson examines the representation of female masculinity in genre literature, namely action narratives and science fiction. Reading female masculinity as queer embodiment, Persson puts two texts driven by a typical action narrative in dialogue with previous research on representations of female masculinity in literature and popular culture, to demonstrate the importance of paying attention to textual genre when analyzing female masculinity. Persson takes the connection between female masculinity and tragedy as a starting point to argue that breaking genre conventions makes possible a reading of heroic female masculinity as oriented away from heteronormative constructions of a good life, as per Sara Ahmed, in effect making possible the depiction of such women not as tragic deviants but as heroically masculine. Persson's careful analysis offers a useful and timely challenge to customary readings and representations of female masculinity in popular media and fiction alike.

Tiina Rosenberg's essay on the lure of the Eurovision Song Contest is an inquiry into what the queer, dyke and feminist interest in what is intended as a mainstream family-oriented national(ist) annual ritual might mean. With great flair, Rosenberg revisits kitsch and camp theories to argue that there is a queer potential in ESC's play on and with taste taboos and social norms, but she also reflects critically on its complicated geopolitical history and possibilities for renewal, and relevance.

In this issue's Were here section, Di Wang and Lena Gross share their deeply personal and simultaneously sharp political reflections on structural inequality through the lens of the unfolding global Covid-I9 pandemic. Wang details the deadly consequences of racist capitalism for queer people of colour when Covid-ı hit New York, through the commemoration of a loved community member and neighbour. Gross reflects on contemporary notions of the 'undiscriminating virus', and problematizes the comparisons between the Covid-I9 pandemic and the HIV/AIDS pandemic often made in media. 
In a way, these texts are examples, and perhaps exemplary, of a queer scholarship that is deeply implicated in complex historical genealogies and intersecting structural inequalities, deftly moving across subjective experiences and global geographies, a scholarship that presents us with forms of theorizing that come from places of deep affect. In the light of critiques of queer studies from scholars and theorists rooted in black theory, decolonial studies and indigenous studies among others, it is imperative to ask questions that challenge and disturb the many normalizing forces for and in queer academic publishing now and in the years to come.

ERIKA ALM and

ELISABETH LUND ENGEBRETSEN

\section{REFERENCES}

Björklund, Jenny \& Dahl, Ulrika. 2020. “A Decade with lambda nordica." lambda nordica 4/2019-I/2020: 7-24.

Boellstorff, Tom. 2007. Queer studies in the house of anthropology. Annual review of anthropology 36:17-35.

Brim, Matt. 2020. Poor queer studies: Confronting elitism in the university. Durham: Duke University Press.

Fleckner, Ester. Website: http://esterfleckner.net/.

Hartman, Saidiya. 2020. "The Death Toll." The Quarantine Files: Thinkers in SelfIsolation. Los Angeles Review of Books. April I4, 2020. https://lareviewofbooks.org/ article/quarantine-files-thinkers-self-isolation.

Lykke, Nina. 2020. Nordic. lambda nordica 4/2019-I/2020: II2-II6. 